\title{
PERSPECTIVE
}

\section{Diagnosis of viral and chlamydial keratoconjunctivitis: which laboratory test?}

\author{
Elfath M Elnifro, Robert J Cooper, Paul E Klapper, Andrew S Bailey, Andrew B Tullo
}

Conjunctivitis and keratitis are common forms of ocular morbidity seen in general practice and eye units. ${ }^{12}$ The aetiology of these diseases includes viral, bacterial, or parasitic infection as well as allergy, trauma, and dietary deficiency. Among the common microbial causes ${ }^{3-7}$ (Table 1) are adenovirus, herpes simplex virus (HSV), and Chlamydia trachomatis. Ocular adenovirus infections occur throughout the world in both sporadic and epidemic forms, and large scale outbreaks of epidemic keratoconjunctivitis can occur in hospitals, schools, military establishments, or factories. ${ }^{8} \mathrm{HSV}$ type 1 ocular infection occurs in all countries with an annual incidence of up to 20.7 per 100000 population and is the most common infective cause of blindness in developed countries. ${ }^{49}$ Trachoma caused by $C$ trachomatis serovars $\mathrm{A}-\mathrm{C}$ is the leading infectious cause of blindness in the world and is a major public health problem in developing countries. ${ }^{10}$ Adult chlamydial conjunctivitis, caused by $C$ trachomatis serovars $\mathrm{D}-\mathrm{K}$, is an oculogenital infection and up to $90 \%$ of patients have concurrent genital infection. ${ }^{11-13}$ Chlamydial neonatal conjunctivitis (ophthalmia neonatorum) develops in $18 \%-74 \%$ of babies born to mothers with genital chlamydial infection. ${ }^{\text {? }}$

This article reviews available diagnostic laboratory techniques for keratoconjunctivitis caused by adenovirus, HSV, and $C$ trachomatis with special emphasis on modern molecular diagnostic techniques. For information on the clinical features, epidemiology, and treatment of these infections the reader is referred to a number of other reviews. ${ }^{8}{ }^{14-17}$
The need for laboratory investigation

Owing to the limited reliability of clinical diagnosis of adenovirus, HSV, and $C$ trachomatis induced keratoconjunctivitis, ${ }^{18-23}$ accurate laboratory investigation for these agents in conjunctival swabs is often valuable. Failure to diagnose ocular adenoviral disease can result in outbreaks of epidemic keratoconjunctivitis. Prompt recognition of the strains of adenovirus causing this condition in patients can, however, help to contain the development of a hospital based epidemic. ${ }^{24} C$ trachomatis infection (particularly with serovars $\mathrm{D}-\mathrm{K}$ ) is usually associated with asymptomatic genitourinary colonisation. ${ }^{25}$ Misdiagnosis of this ocular infection may represent a missed opportunity to detect infection of the genital tract which can ultimately result in a series of complications including pelvic inflammatory disease, epididymitis, ectopic pregnancy, and infertility in the patient and/or partner. ${ }^{11-13}{ }^{25}$ In addition, delay in diagnosing chlamydial conjunctivitis and the use of inappropriate antibiotic treatment might trigger chlamydial persistence. ${ }^{26}$ The availability of appropriate treatment for chlamydia, ${ }^{16} \mathrm{HSV},{ }^{17}$ and possibly adenovirus ${ }^{27}$ together with the potentially serious residual morbidity of these infections clearly justifies the need for accurate laboratory investigation in cases of keratoconjunctivitis.

\section{Conventional laboratory techniques}

The conventional techniques for diagnosing viral and chlamydial keratoconjunctivitis include conjunctival cytological investigation ${ }^{28-30}$; inoculation of susceptible cell lines followed by observation of cytopathic effect or visualisation

Table 1 Viral and chlamydial causes of infectious conjunctivitis

\begin{tabular}{|c|c|c|}
\hline Causative agent (references) & Differential diagnosis & Epidemiology \\
\hline \multicolumn{3}{|l|}{ DNA viruses: } \\
\hline \multirow[t]{3}{*}{ Adenovirus (3) } & EKC & $\begin{array}{l}\text { Primarily types } 8 \text { and } 19 \text {, but types } 2-5,7,9,11,14,16,21-23 \text {, and } 37 \text { have also been associated } \\
\text { with EKC. Highly contagious and transmitted by hand to eye contact, instruments, and solutions. }\end{array}$ \\
\hline & PCF & $\begin{array}{l}\text { Primarily types } 3,4 \text {, and } 7 \text {; occasionally type } 5 \text {. Contagious; droplet transmission, particularly in } \\
\text { families. }\end{array}$ \\
\hline & NSFC & A number of serotypes have been reported including $1-11,14-17,19,20,22$, and 26 . \\
\hline $\operatorname{HSV}(4,5)$ & Conjunctivitis; keratitis or $\mathrm{KC}$ & $\begin{array}{l}\text { HSV-1 or HSV-2; conjunctivitis is most common in adults and children } 1-5 \text { years of age; recurrent } \\
\text { disease is common; leading infectious cause of blindness in developed countries. }\end{array}$ \\
\hline \multicolumn{3}{|r|}{ T } \\
\hline Picornavirus & AHC & EV70; CA24; common (epidemic or endemic forms) in developing countries; highly contagious. \\
\hline Measles virus (6) & MVO & $\begin{array}{l}\text { Common cause of childhood blindness in developing countries. HSK may complicate measles in } \\
\text { developing countries. }\end{array}$ \\
\hline \multicolumn{3}{|r|}{ 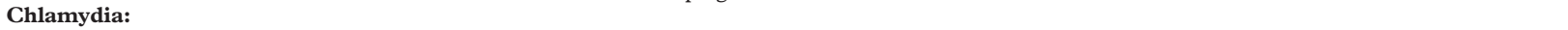 } \\
\hline \multirow[t]{4}{*}{ C trachomatis (7) } & $\mathrm{NCO}$ & $\begin{array}{l}\text { The most common form of infectious ophthalmia neonatorum today; occurs in babies born to } \\
\text { mothers with genital infection serovars } \mathrm{D}-\mathrm{K} \text {. }\end{array}$ \\
\hline & $\mathrm{ACO}$ & $\begin{array}{l}\text { Oculogenital infection caused by serovars } \mathrm{D}-\mathrm{K} \text {, sometimes by B, and rarely by C; common in } \\
\text { developed countries and urban areas of developing countries. }\end{array}$ \\
\hline & Trachoma & $\begin{array}{l}\text { Most common cause of preventable blindness in the world and common in rural areas of } \\
\text { developing countries particularly in Africa, the Middle East, and Asia; caused by serovars A-C. }\end{array}$ \\
\hline & LGV conjunctivitis & $\begin{array}{l}\text { Very rare and is caused by serotypes L-1, L-2, and L3; transmission either venereally or } \\
\text { accidentally in the laboratory. }\end{array}$ \\
\hline
\end{tabular}

$\mathrm{EKC}=$ epidemic keratoconjunctivitis $\mathrm{PCF}=$ pharyngoconjunctival fever $\mathrm{NSFC}=$ non-specific follicular conjunctivitis; $\mathrm{KC}=$ keratoconjunctivitis; $\mathrm{AHC}=$ acute haemorrhagic conjunctivitis; $\mathrm{MVO}=$ measles virus ophthalmia; $\mathrm{NCO}=$ neonatal chlamydial ophthalmia; $\mathrm{ACO}=$ adult chlamydial ophthalmia; $\mathrm{LGV}=$ lymphogranuloma venereum; HSK=herpes simplex keratitis; $\mathrm{HSV}=$ herpes simplex virus; $\mathrm{EV}=$ =nterovirus; $\mathrm{CA}=$ Coxsackie virus type $\mathrm{A}$. 
Table 2 Sensitivities and specificities of antigen detection techniques for the diagnosis of adenovirus, HSV, and chlamydial keratoconjunctivitis in comparison with cell culture isolation

\begin{tabular}{|c|c|c|c|c|c|}
\hline $\begin{array}{l}\text { Causative } \\
\text { agent }\end{array}$ & $\begin{array}{l}\text { Test } \\
\text { format }\end{array}$ & Commercial name & $\begin{array}{l}\text { Sensitivity } \\
(\%)\end{array}$ & $\begin{array}{l}\text { Specificity } \\
(\%)\end{array}$ & Reference \\
\hline \multirow[t]{9}{*}{ Adenovirus } & \multirow[t]{5}{*}{ EIA } & $\begin{array}{l}\text { Cambridge } \\
\text { Adenoclone }\end{array}$ & 80.6 & 100 & 42 \\
\hline & & & 62.3 & 100 & 43 \\
\hline & & $\begin{array}{l}\text { Cambridge } \\
\text { Adenoclone }\end{array}$ & 77 & 100 & 44 \\
\hline & & $\begin{array}{l}\text { Cambridge } \\
\text { Adenoclone }\end{array}$ & 38 & 100 & 45 \\
\hline & & $\begin{array}{l}\text { Cambridge } \\
\text { Adenoclone }\end{array}$ & 50.5 & 100 & $46^{\star}$ \\
\hline & IC & SAS Adenotest & 54.7 & 97.1 & $46^{\star}$ \\
\hline & IF & & 79 & 100 & 42 \\
\hline & \multirow[t]{2}{*}{ IDB } & & 85.3 & 92.2 & 47 \\
\hline & & & 67 & 93 & 48 \\
\hline \multirow[t]{7}{*}{ HSV } & IIF & & 97 & 73 & 49 \\
\hline & DIF & Syva Microtrak & 86 & 100 & $50 \dagger$ \\
\hline & \multirow[t]{4}{*}{ EIA } & Kodak Surecell & 37.5 & 81.3 & 51 \\
\hline & & Kodak Surecell & 27 & 80 & 52 \\
\hline & & $\begin{array}{l}\text { DuPont } \\
\text { Herpchek }\end{array}$ & 65 & 100 & 53 \\
\hline & & & 26 & 90 & 53 \\
\hline & IF & & 59 & 100 & 53 \\
\hline \multirow[t]{11}{*}{$C$ trachomatis } & \multirow[t]{6}{*}{ DIF } & \multirow[t]{2}{*}{ Syva Microtrak } & 100 & 99 & 54 \\
\hline & & & 100 & 97.5 & 55 \\
\hline & & Syva Microtrak, & 57 & 81 & 56 \\
\hline & & \multirow[t]{3}{*}{ Syva Microtrak } & 83.3 & 96.6 & 57 \\
\hline & & & 52 & 98 & 29 \\
\hline & & & 100 & 52 & 34 \\
\hline & IPO & & 54 & 96 & 29 \\
\hline & \multirow[t]{4}{*}{ EIA } & $\begin{array}{l}\text { Abbott } \\
\text { Chlamydiazyme }\end{array}$ & 71 & 97 & 56 \\
\hline & & $\begin{array}{l}\text { Abbott } \\
\text { Chlamydiazyme }\end{array}$ & 88 & 99 & 58 \\
\hline & & Kodak Surecell & 40 & 100 & 59 \\
\hline & & & 92.64 & 94.54 & $60 \ddagger$ \\
\hline
\end{tabular}

$\mathrm{DIF}=$ direct immunofluorescence; $\mathrm{IPO}=$ immunoperoxidase; $\mathrm{EIA}=$ enzyme immunoassay; $\mathrm{IIF}=$ indirect immunofluorescence; $\mathrm{IF}=$ immunofiltration;

$\mathrm{IC}=$ immunochromatography; IDB=immune dot blot.

*Compared with PCR.

†Compared with clinical diagnosis.

‡Compared with DIF.

using various chemical or immunological staining techniques ${ }^{31-33}$; examination of blood and/or tears for various classes of antibodies ${ }^{34-41}$; and detection of viral or chlamydial antigens in conjunctival and corneal specimens $^{29} 3_{42-60}$ (Table 2). However, the pitfalls of these conventional techniques are numerous. Traditional cytological investigation is insensitive and subjective. ${ }^{28}{ }^{29}$ Cell culture isolation requires viable organisms necessitating special transport media and prompt transport of specimens between patient and laboratory. It is costly and time consuming but remains the "gold standard" as isolation of an infectious agent is definitive and allows further characterisation.

Serodiagnosis (IgM antibody detection) of infection is not always possible during the acute stages of illness and false positive results may arise because of cross reactivity with other related pathogens, or if the tear film is assessed, through the transudation of antibodies from blood into tears. Antigen detection techniques circumvent the requirement for preservation of infectivity required for culture but can produce false negative and false positive test results. In addition, the wide range of sensitivity and specificity values obtained with antigen detection tests (Table 2) is not only influenced by the quality of the test itself, but by the quality of the gold standard test used (culture or other comparative test); the "cut off" value for positive and negative results; the experience of the observer to discriminate between specific and non-specific staining in the case of the direct immunofluorescence test; and false positive results due to cross reactivity with other pathogens in the case of enzyme immunoassays.

The introduction of diagnostic test procedures based on nucleic acid amplification techniques has led to a reappraisal of the use of conventional methods of diagnosis. Nucleic acid amplification techniques currently available or under active development include the polymerase chain reaction (PCR), the ligase chain reaction (LCR), transcription based amplification system, Q $\beta$ replicase amplification, cycling probe reaction, strand displacement amplification, and branched DNA signal amplification. ${ }^{61}$ Of these techniques, PCR, the first of the nucleic acid amplification methods to be described, is the most developed.

\section{Polymerase chain reaction (PCR)}

PCR allows the identification of extremely small quantities of DNA with a very high degree of specificity. The test has revolutionised the diagnosis of microbial diseases ${ }^{62}{ }^{63}$ and since its first use in eye disease in $1990,{ }^{64}$ the test is now being widely used in clinical ophthalmology. ${ }^{65}{ }^{66}$ Owing to the sensitivity and speed of the PCR, and its use of small sample volumes, the technique has been shown to be of great value in the diagnosis of infections involving both the ocular surface and the orbit ${ }^{21}{ }^{57}$ 67-97 $^{6}$ (Table 3). A number of studies have evaluated the use of PCR as a diagnostic tool for the detection of adenovirus, HSV, and $C$ trachomatis in conjunctival swabs.

ADENOVIRUS

PCR may be the only means by which rapid and reliable diagnosis of adenoviral keratoconjunctivitis can be achieved. The technique has been shown to be more sensitive, accurate, and rapid than culture for detecting and typing adenovirus in cases of conjunctivitis ${ }^{67}{ }^{68}$ In addition, PCR appears to be more sensitive than immunoassay in detection of ocular adenovirus infections. For example, Kinchington et al ${ }^{69}$ evaluated the application of PCR in 107 ocular swab samples and correlated the results with those obtained with tissue culture and a commercial immunoassay (Adenoclone). The PCR was positive in 46 of 58 adenoclone negative, culture positive swabs, and in 11 of 11 adenoclone positive, culture positive swabs. Only one of 38 non-adenoviral ocular swab samples was positive by PCR giving an overall specificity of $97.3 \%$. These results demonstrate the superiority of PCR in terms of speed over tissue culture isolation and in sensitivity over immunoassay.

In our own laboratory, the overall sensitivity of PCR for detection of adenovirus in eye swabs was similar to that of cell culture and superior to that of antigen detection by immune dot-blot test. ${ }^{71}$ More recently, using a newly designed adenovirus primer pair, we have a PCR which is significantly more sensitive than culture. Of 415 eye swabs positive by culture and/or PCR, $386(93 \%)$ were positive by PCR compared with 248 (59\%) by cell culture. ${ }^{72}$

\section{HERPES SIMPLEX VIRUS}

Few studies have compared PCR with conventional techniques. This is probably because the clinical features of herpetic eye disease are often strongly suggestive and culture results are available much sooner (3 days) than those of adenovirus (up to 4 weeks) and chlamydia (5 days). Nevertheless, owing to its speed and sensitivity, PCR is a useful diagnostic tool for $\mathrm{HSV}$ infection of the ocular surface. $^{2173-75}$ Yamamoto et $a l^{73}$ utilised PCR for the detection of HSV genomic sequences in tear film from patients with clinically diagnosed HSV keratitis. The PCR was positive in 12 of 12 epithelial keratitis specimens, two of six stromal keratitis, but in none of 20 normal specimens. In another study by Kowalski et $a l^{21}$ utilising cell culture as a gold standard test, PCR was shown to be 
Table 3 Applications of PCR in ophthalmic infectious diseases

\begin{tabular}{|c|c|c|c|}
\hline Causative agent & Ocular site & Clinical diagnosis & Reference \\
\hline \multicolumn{4}{|l|}{ Viruses: } \\
\hline Adenovirus & Conjunctiva & KC & $67-72$ \\
\hline \multirow[t]{3}{*}{ HSV } & Tear film & keratitis & 73,74 \\
\hline & Cornea or conjunctiva & keratitis or $\mathrm{KC}$ & $21,75,76$ \\
\hline & Aqueous & uveitis & 77,78 \\
\hline EV70 & Conjunctiva & AHC & 79 \\
\hline \multirow[t]{2}{*}{ VZV } & Aqueous and vitreous & retinal necrosis & 78 \\
\hline & Vitreous & ophthalmic zoster & 80 \\
\hline \multirow[t]{2}{*}{ EBV } & Aqueous and vitreous & retinal necrosis & 81 \\
\hline & Vitreous & Vogt-Koyanagi-Harada syndrome & 82 \\
\hline CMV & Aqueous, subretinal, and vitreous & chorioretinal inflammatory disease or retinitis & $80,83,84$ \\
\hline HPV & Conjunctiva & conjunctival carcinoma & 85 \\
\hline \multicolumn{4}{|l|}{ Bacteria: } \\
\hline C trachomatis & Conjunctiva & chlamydial conjunctivitis & $56,86-95$ \\
\hline Mycobacteria & Vitreous and uveal tissue & endophthalmitis & 96 \\
\hline \multicolumn{4}{|l|}{ Parasites: } \\
\hline \multirow[t]{2}{*}{ Toxoplasma gondii } & Aqueous and vitreous & retinochoroiditis & 78 \\
\hline & Ocular tissue sections & ocular toxoplasmosis & 97 \\
\hline
\end{tabular}

$\mathrm{KC}=$ keratoconjunctivitis; $\mathrm{EV70}=$ enterovirus $70 ; \mathrm{AHC}=$ acute haemorrhagic conjunctivitis; $\mathrm{VZV}=$ varicella zoster virus; $\mathrm{EBV}=\mathrm{Epstein}-\mathrm{Barr}$ virus; $\mathrm{CMV}=$ cytomegalovirus; $\mathrm{HPV}=$ human papillomavirus.

significantly more sensitive (95\%) in diagnosing herpetic ocular disease than diagnosis by clinical examination $(55 \%)$.

\section{CHLAMYDIA TRACHOMATIS}

For $C$ trachomatis, the PCR has been shown to be as or more sensitive than conventional techniques. ${ }^{57}{ }^{86-95}$ Bobo et $a l^{94}$ investigated the use of PCR in 234 Tanzanian children who were clinically classified as having no sign of trachoma $(n=97)$, follicular trachoma $(n=100)$, or intense inflammatory trachoma $(\mathrm{n}=37)$. The PCR detected $C$ trachomatis in $24 \%, 54 \%$, and $95 \%$ of subjects, respectively, compared with detection by direct immunofluorescence of $1 \%, 28 \%$, and $60 \%$, respectively. The overall prevalence of chlamydial eye infection was $48 \%$ by PCR compared with $22 \%$ by direct immunofluorescence. In addition, this study showed the utility of PCR as a suitable method for field use owing to ease of specimen collection and transport.

In the United States, Talley et $a l^{90}$ screened ocular swabs from 30 consecutive patients with follicular conjunctivitis for adenovirus, HSV, and $C$ trachomatis. In this study, PCR was compared with cell culture and direct immunofluorescence test for the detection of $C$ trachomatis. Only four patients were positive for $C$ trachomatis by PCR. Two of the four patients were positive by cell culture and one of four patients was positive by direct immunofluorescence. Thus, PCR appeared to be an equally specific and more sensitive method than cell culture or the direct immunofluorescence test. In another study Tabrizi et al ${ }^{93}$ compared culture and PCR techniques in the detection of $C$ trachomatis in 200 clinical samples including eye swabs $(30 \%)$. A total of 173 specimens were assessable by PCR of which 24 (13.8\%) were positive by both methods and four specimens were positive by PCR and negative by culture. Overall the PCR was $100 \%$ sensitive and $97.3 \%$ specific compared with cell culture. Haller et $a \bar{P}^{7}$ evaluated the use of PCR, direct immunofluorescence, and serology for the detection of chlamydial IgA and IgG in 93 patients with follicular conjunctivitis. In comparison with cell culture, the sensitivities of PCR, direct immunofluorescence, and the three assays for $\operatorname{IgA}$ or $\operatorname{IgG}$ were $100 \%, 83.3 \%$, and $62.5 \%-75 \%$ or $37.5 \%-100 \%$, respectively, with specificities of $100 \%$, $96.6 \%$, and $70.6 \%-81 \%$ or $47.3 \%-64.8 \%$, respectively. In a study of 75 cases of neonatal conjunctivitis, a commercially available PCR assay, Roche Amplicor, was found to be equivalent to culture for conjunctival specimens with sensitivity, specificity, and positive and negative predictive values of $92.3,100,100$, and $98.4 \%$, respectively. ${ }^{95}$ PCR is a valuable epidemiological tool for detecting and genotyping ocular strains of $C$ trachomatis from cases of inclusion conjunctivitis and trachoma. ${ }^{87} 89$
RELIABILITY

Because of its sensitivity, false positive results due to the carryover of small amounts of the products of previous PCR tests may be encountered. Such problems can be avoided by strict application of a variety of preventative measures. ${ }^{98}$ False negative results may arise as a result of failure of PCR amplification. The most common cause of PCR failure is due to the introduction of inhibitors with the test sample. ${ }^{99}$ A variety of sample preparation techniques are now available to help avoid such problems and control for sample inhibition can be accomplished by the inclusion of internal control molecules ${ }^{100}$ or by amplification of human DNA in the sample (for example, $\beta$ globin gene)..$^{76}$

AUTOMATION

Nucleic acid amplification procedures may be automated to improve the reproducibility, speed, and overall cost of tests. An example is the Cobas Amplicor (Roche Molecular Systems) automated PCR system ${ }^{101}$ and the ligase chain reaction test kit (Abbott Diagnostics Ltd). ${ }^{102}$ While commercial test procedures and automation are, in relation to ocular disease, currently only available for $C$ trachomatis, ${ }^{6295}$ the available test repertoire is increasing. The more widespread application of these tests is anticipated, particularly as they overcome the problem of variable sensitivity and specificity between laboratories using their own "in house" procedures.

\section{Discussion and conclusions}

The ideal test for diagnosing ocular pathogens has been defined as one whose result is available before the patient leaves the doctor's office. ${ }^{103}$ However, achieving sensitivity, specificity, low cost, long term shelf storage, and ease of performance by office staff without the need for expensive equipment or hazardous reagents currently presents a formidable technological challenge. Although PCR achieves the accuracy needed for diagnosis of ocular infectious agents, it still lacks the speed and simplicity required for an office based test. The anticipated introduction of effective treatment of adenoviral keratoconjunctivitis ${ }^{27}$ poses a real challenge to the applicability of the emerging tests discussed in this review. To allow dispensing of treatment and discharge of the patient from clinic (where cases of adenoviral keratoconjunctivitis pose a real threat to other patients and staff) test results would be required within 10-30 minutes. At the present time only immunochromatography ${ }^{46}$ can provide information within such a time frame but the low sensitivity of such tests is a major drawback. 
The choice of the optimal technique for diagnosing viral and chlamydial keratoconjunctivitis depends upon the efficiency, speed, and cost of the test. The performance of conventional laboratory procedures is relatively poor and the interpretative difficulties documented with these tests are well recognised. Owing to their inherent sensitivity and high specificity, nucleic acid amplification procedures, in particular PCR, are recognised as the ultimate modern diagnostic tool for the identification of adenovirus, HSV, and $C$ trachomatis in clinical eye swab samples. However, in laboratories without access to PCR, the conventional techniques of enzyme immunoassay, culture, and direct immunofluorescence are useful for diagnosing adenovirus, HSV, and chlamydia. The direct immunofluorescence test can, however, only be recommended if a small number of specimens are submitted and examined by skilled and experienced microscopists and although commercial enzyme immunoassays have the advantages of low cost and suitability for testing large numbers of specimens, the false positive and false negative results generated are serious disadvantages. Particularly in relation to $C$ trachomatis infection, inaccurate diagnosis in a patient being investigated for conjunctivitis and not sexually transmitted disease, can lead to difficult communication with the patient and even litigation.

A conceptual difficulty with all nucleic acid amplification procedures is the finding of positive detection of nucleic acid in the absence of viable organisms (as determined by culture) or of antigen (immunoassay). The current sophistication of PCR means that provided due attention is given to intralaboratory quality control including rigorous application of anti-cross contamination procedures, ${ }^{98}$ the finding of the nucleic acid of an infectious organism in an ocular specimen is significant. The presence of residual nucleic acid usually indicates that infection persists well beyond the period indicated by cell culture or antigen detection tests. Factors generated in the course of the clinical response such as the elaboration of antibodies, interleukin 1, interferon gamma, and tumour necrosis factor (TNF) might inhibit or alter the metabolic capacity, surface receptor expression, or infectivity and therefore culturability or the antigenicity of the organism. In this way the infectivity might fall while the organism, containing DNA, is still detectable by PCR.

Nucleic acid amplification may, as has happened with other non-culture diagnostic procedures, also detect an infectious agent in circumstances which are not consistent with the clinical features under investigation. Such findings should not be dismissed because these diagnostic procedures have proved to be a powerful tool in elucidating the aetiology of several ocular diseases previously classified as idiopathic.

A further item of value in detection of nucleic acid in ocular specimens is in the assessment of treatment failure. Until recently, treatment failure was defined solely on the basis of positive culture. For the reasons outlined above, the lack of detection of infectious organisms may not signal the end of a disease process. Non-culture test results, particularly those of high sensitivity, are very probably a more reliable indicator of treatment failure. The continued development of nucleic acid amplification procedures will lead to the wider availability of quantitative procedures which will refine our ability to monitor the efficiency and progress of therapeutic regimens.

The continued development of nucleic acid amplification procedures will also lead to a reduction in the overall cost of diagnosing viral and chlamydial keratoconjunctivitis. Already PCR procedures are available to allow the simultaneous investigation of several pathogens using one test in which the three or more organism specific oligonucleotide primer pairs are included (multiplex PCR). Such tests allow the testing of a single sample and permit easy identification of possible, albeit rare, concurrent infection. ${ }^{104-107}$ In our own laboratory, for example, a multiplex PCR has been developed for the simultaneous investigation of adenovirus, $\mathrm{HSV}$, and $\beta$ globin in ocular swabs ${ }^{76}$ and, currently, we are modifying the technique to include $C$ trachomatis detection.

In conclusion, nucleic acid amplification procedures are valuable modern techniques for the diagnosis of infectious ocular disease. The availability of automation and the more widespread availability of commercial assays will facilitate the use of these techniques in routine laboratories. These techniques are evolving rapidly and are likely to have an increasingly important role in therapeutic management.

ELFATH M ELNIFRO ROBERT J COOPER

Division of Virology, Department of Pathological Sciences,

University of Manchester

PAUL E KLAPPER

ANDREW S BAILEY

Clinical Virology Laboratory, Manchester Royal Infirmary, Manchester

ANDREW B TULLO

Royal Eye Hospital, Manchester

Correspondence to: Mr Elfath M Elnifro, University Virology, 3rd Floor,

Clinical Sciences Building, Manchester Royal Infirmary, Oxford Road,

Manchester M13 9WL.

1 Dart JKG. Eye disease at a community health centre. BMF 1986;293:1477-

2 Jones NP, Hayward JM, Khaw PT, et al. Function of an ophthalmic accident and emergency department: results of a six month survey. BMF 1986;292: 188-90.

3 Asbell PA, deLuise VP, Bartolomei A. Viral conjunctivitis. In: Tabbara KF, Hyndiuk RA, eds. Infections of the eye. London: Little, Brown, 1996:453-70. 4 Leisegang TJ, Melton J, Daly PJ, et al. Epidemiology of ocular herpes simplex. Arch Ophthalmol 1989;107:1155-9.

5 Oh JO. Ocular infections of herpes simplex virus type 2 in adults. In: Darrel RW, ed. Viral diseases of the eye. Philadelphia: Lea \& Febiger, 1985:59-62.

6 Foster A, Sommer A. Corneal ulceration, measles, and childhood blindness in Tanzania. Br 7 Ophthalmol 1987;71:331-43.

7 Tabbara KF. Chlamydia: trachoma and inclusion conjunctivitis. In: Tabbara $\mathrm{KF}$, Hyndiuk RA, eds. Infections of the eye. London: Little, Brown, 1996:433-51.

8 Ford E, Nelson KE, Warren D. Epidemiology of epidemic keratoconjunctivitis. Epidemiol Rev 1987; 9:244-61.

9 Darougar S, Monnickendam MA, Woodland RM. Management and prevention of ocular viral and chlamydial infections. CRC Crit Rev Microbiol 1989;16:369-417

10 Tabbara KF, Ross-Degnan D. Blindness in Saudi Arabia. FAMA 1986;255: 3378-84.

11 Stenberg K, Mardh P. Genital infection with Chlamydia trachomatis in patients with chlamydial conjunctivitis: unexplained results. Sex Transm Dis 1991;18:1-4.

12 Postema EJ, Remeijer L, van der Meijden WI. Epidemiology of genital chlamydial infections in patients with chlamydial conjunctivitis; a retrospective study. Genitourin Med 1996;72:203-5.

13 Garland SM, Malatt A, Tabrizi S, et al. Chlamydia trachomatis conjunctivitis, prevalence and association with genital tract infection. Med f Aust 1995;162:363-6.

14 Morrow GL, Abbott RL. Conjunctivitis. Am Fam Physician 1998;57:735-46

15 Gottsch JD. Surveillance and control of epidemic keratoconjunctivitis. Trans

Am Ophthalmol Soc 1996;94:539-84.
16 Nakagawa H. Treatment of chlamydial conjunctivitis. Ophthalmologica 1997;21(suppl 1):25-8.

17 Lee SY, Laibson PR. Medical management of herpes simplex ocular infections. Int Ophthalmol Clin 1996;36:85-97.

18 Wishart PK, James C, Wishart MS, et al. Prevalence of acute conjunctivitis caused by chlamydia, adenovirus, and herpes simplex virus in an ophthalmic casualty unit. Br F Ophthalmol 1984;68:653-5.

19 Darougar S, Woodland RM, Walpita P. Value and cost effectiveness of double culture tests for diagnosis of ocular viral and chlamydial infections. $\mathrm{Br} \mathcal{F}$ Ophthalmol 1987;71:673-5.

20 Fitch CP, Rapoza PA, Owens S, et al. Epidemiology and diagnosis of acute conjunctivitis at an inner-city hospital. Ophthalmology 1989;96:1215-20.

21 Kowalski RP, Gordon YJ, Romanowski EG, et al. A comparison of enzyme immunoassay and polymerase chain reaction with the clinical examination for diagnosing ocular herpetic disease. Ophthalmology 1993;100:530-3.

22 Rao SK, Madhavan HN, Radmanabhan P, et al. Ocular chlamydial infections, clinico-microbiological correlation. Cornea 1996;15:62-5.

23 Kowalski RP, Romanowski EG, Cruz TA, et al. Immunoassay, PCR or slit lamp diagnosis: which is superior for detecting ocular herpes simplex virus lamp diagnosis: which is superior for detecting ocular herp
disease? Invest Ophthalmol Vis Sci 1991;32(suppl):805.

24 Ankers HE, Klapper PE, Cleator GM, et al. The role of a rapid diagnostic test (adenovirus immune dot-blot) in the control of an outbreak of adenovirus type 8 keratoconjunctivitis. Eye 1993;7(suppl):15-17. 
25 Taylor-Robinson D, Thomas BJ. The role of Chlamydia trachomatis in genital-tract and associated diseases. F Clin Pathol 1980;33:205-33.

26 Beatty WL, Morrison RP, Byrne GI. Persistent Chlamydiae: from cell culture to a paradigm for chlamydial pathogenesis. Microbiol Rev 1994;58: 686-99

27 Gordon YJ, Naesens L, DeClercq E, et al. Treatment of adenoviral conjunctivitis with topical cidofovir. Cornea 1996;15:546.

28 Kobayashi TK, Sato S, Tsubota K, et al. Cytological evaluation of adenoviral follicular conjunctivitis by cytobrush. Ophthalmologica 1991;202:15660 .

29 Madhavan HN, Rao SK, Natarajan K, et al. Evaluation of laboratory tests for diagnosis of chlamydial infections in conjunctival specimens. Indian $\mathcal{f}$ Med Res 1994;100:5-9.

30 Thiel MA, Bossart W, Bernauer W. Improved impression cytology techniques for the immunopathological diagnosis of superficial viral infectechniques for the immunopathological
tions. Br F Ophthalmol 1997;81:984-8.

31 Evans RT, Woodland RM. Detection of chlamydiae by isolation and direct examination. Br Med Bull 1983;39:181-6.

32 Darougar S, Walpita P, Thaker U, et al. Rapid culture test for adenovirus isolation. Brf Ophthalmol 1984;68:405-8.

33 Walpita P, Darougar S, Thaker U. A rapid and sensitive culture test for detecting herpes simplex virus from the eye. Brf Ophthalmol 1985;69:6379.

34 Bialasiewicz AA, Jahn GJ. Evaluation of diagnostic tools for adult chlamydial keratoconjuctivitis. Ophthalmology 1987;94:532-7.

35 Herrmann B, Stenberg K, Mardh P. Immune response in chlamydial conjunctivitis among neonates and adults with special reference to tear IgA. 99:69-74.

36 Buisman NJF, Ossewaarde JM, Rieffe M, et al. Chlamydia keratoconjunctivitis: determination of Chlamydia trachomatis specific secretory immunoglobulin A in tears by enzyme immunoassay. Graefes Arch Clin Exp Ophthalmol 1992;230:411-15.

37 Haller E-M, Auer-Grumbach P, Stuenzner D, et al. Detection of antichlamydial antibodies in tears: a diagnostic aid? Ophthalmology 1997;104:125-30.

38 Mannion PT, Mallison H, Treharne JD. Serological diagnosis with the Chlamydia Spot-IF test. $\mathcal{7}$ Med Microbiol 1991;35:244-8.

39 Forsey T, Darougar S. Indirect microimmunofluorescence test for detecting type-specific antibodies to herpes simplex virus. F Clin Pathol 1980;33:171-

40 Pedersen B, Møller Anderson S, Klauber A, et al. Secretory IgA specific for herpes simplex virus in lacrimal fluid from patients with herpes keratitis-a possible diagnostic parameter. Br F Ophthalmol 1982;66:648-53

41 Fox PD, Khaw PT, McBride BW, et al. Tear and serum antibody levels in ocular herpetic infections diagnostic precision of secretory IgA. $\mathrm{Br} \mathcal{F} \mathrm{Oph}$ thalmol 1986;70:584-8.

42 Kowalski RP, Gordon YJ. Comparison of direct rapid tests for the detection of adenovirus antigen in routine conjunctival specimens. Ophthalmology 1989;96:1106-9.

43 Bryden AS, Bertrand J. Diagnosis of adenovirus conjunctivitis by enzyme immunoassay. Br 7 Biomed Sci 1996;53:182-4.

44 Wiley L, Springer D, Kowalski RP, et al. Rapid diagnostic test for ocular adenovirus. Ophthalmology 1988;95:431-3.

45 Wiley LA, Roba LA, Kowalski RP, et al. A 5-year evaluation of the adenoclone test for the rapid diagnosis of adenovirus from conjunctival swabs. Cornea 1996;15:363-7.

46 Uchio E, Aoki K, Saitoh W, et al. Rapid diagnosis of adenoviral conjunctivitis on conjunctivial swabs by 10 -minute immunochromatography. Ophthalmology 1997;104:1294-9.

47 Killough R, Klapper PE, Bailey AS, et al. An immune dot-blot technique for the diagnosis of ocular adenovirus infection. F Virol Methods 1990;30:197204.

48 Morris DJ, Klapper PE, Killough R, et al. Prospective study of adenovirus antige

49 Schwab IR, Raju VK, McClung J. Indirect immunofluorescent antibody diagnosis of herpes simplex with upper tarsal and corneal scrapings. Ophthalmology 1986;93:752-6.

50 Ruiz C, Labella F, Duran JA, et al. Accuracy of direct immunofluorescence for the diagnosis of herpes simplex keratitis. Invest Ophthalmol Vis Sci 1991; 32(suppl): 805 .

51 Portnoy SL, Kowalski R, Karenchak L, et al. Evaluation of the Kodak Surecell test for ocular herpes simplex virus diagnosis. Invest Ophthalmol Vis Sci 1990;31 (suppl):221

52 Kowalski RP, Portnoy SL, Karenchak LM, et al. The evaluation of the Kodak Surecell test for the detection of ocular herpes simplex virus. $A m \mathcal{F}$ Ophthalmol 1991;112:214-5.

53 Kowalski RP, Gordon YJ. Evaluation of immunologic tests for the detection of ocular herpes simplex virus. Ophthalmology 1989;96:1583-6.

54 Hawkins DA, Wilson RS, Thomas BJ, et al. Rapid, reliable diagnosis of chlamydial ophthalmia by means of monoclonal antibodies. Br F Ophthalmol 1985;69:640-4.

55 Potts MJ, Paul ID, Roome APCH, et al. Rapid diagnosis of Chlamydia trachomatis infection in patients attending an ophthalmic casualty departchomatis infection in patients attendin
ment. Br $\mathcal{F}$ Ophthalmol 1986;70:677-80.

56 Sheppard JD, Kowalski RP, Meyer M, et al. Immunodiagnosis of adult chlamydial conjunctivitis. Ophthalmology 1988;95:434-43.

57 Haller E, Auer-Grumbach P, Stuerzner D, et al. Evaluation of two nonculture antigen tests and three serotests for detection of anti-chlamydial antibodies in the diagnosis of ocular chlamydial infections. Graefes Arch Clin Exp Ophthalmol 1996;234:510-4

58 Stenberg K, Herrmann B, Dannevig L, et al. Culture, ELISA and immunofluorescence tests for the diagnosis of conjunctivitis caused by Chlamydia trachomatis in neonates and adults. APMIS 1990;98:514-20.

59 Tanitisira JG, Kowalski RP, Gordon YJ. Evaluation of the Kodak Surecell chlamydia test for the laboratory diagnosis of adult inclusion conjunctivitis. Ophthalmology 1995;102:1035-7.

60 Mohantly S, Satpathy G, Mittal S, et al. Development of an antigen capture enzyme immunoassay using genus specific monoclonal antibodies for detection of chlamydia in clinical specimens. Indian $f$ Med Res 1996;103:77-83.

61 Wolcott MJ. Advances in nucleic acid-based detection methods. Clin Microbiol Rev 1992;5:370-86.
62 Wagar EA. Direct hybridisation and amplification applications for the diagnosis of infectious diseases. F Clin Lab Anal 1996;10:312-25.

63 Emmanuel PJ. Polymerase chain reaction from bench to bedside: applications for infectious disease. F Fla Med Assoc 1993;80:627-30.

64 Pflugfelder SC, Crouse C, Atherton S. Detection of Epstein Barr virus genomes in normal human lacrimal glands. F Clin Microbiol 1990;28:102632

65 Della GN. Molecular biology in ophthalmology: a review of principles and recent advances. Arch Ophthalmol 1996;114:457-63.

66 Adleberg JM, Wittwer C. Use of the polymerase chain reaction in the diagnosis of ocular disease. Curr Opin Ophthalmol 1995;6:80-5.

67 Saitoh-Inagawa W, Oshima A, Aoki K, et al. Rapid diagnosis of adenoviral conjunctivitis by PCR and restriction fragment length polymorphism analysis. F Clin Microbiol 1996;34:2113-6.

68 Pring-Åkerblom P, Adrian T. Type- and group specific polymerase chain reaction for adenovirus detection. Res Virol 1994;145:25-35.

69 Kinchington PR, Turse SE, Kowalski RP, et al. Use of polymerase chain reaction for the detection of adenoviruses in ocular swab specimens. Invest Ophthalmol Vis Sci 1994;35:4126-34.

70 Morris DJ, Bailey RJ, Cooper RJ, et al. Polymerase chain reaction for rapid detection of ocular adenovirus infection. F Med Virol 1995;46:126-32.

71 Hussain MAS, Costello P, Morris DJ, et al. Comparison of primer sets for detection of faecal and ocular adenovirus infection using the polymerase chain reaction. $\mathcal{f}$ Med Virol 1996;49:187-94

72 Cooper RJ, Yeo AC, Bailey AS, et al. Adenovirus polymerase chain reaction assay for rapid diagnosis of conjunctivitis. Invest Ophthalmol Vis Sci 1999;40:90-5.

73 Yamamoto S, Shimomura Y, Kinoshita S, et al. Detection of herpes simplex virus DNA in human tear film by the polymerase chain reaction. Am $\mathcal{F}$ Ophthalmol 1994;117:160-3.

74 Tei M, Nishida K, Kinoshita S. Polymerase chain reaction detection of herpes simplex virus in tear fluid from a typical herpetic epithelial keratitis after penetrating keratoplasty. Am f Ophthalmol 1996;122:732-5.

75 Crouse CA, Pflugfelder SC, Pereira IE, et al. Diagnosis of herpetic ocular disease using PCR. Invest Ophthalmol Vis Sci 1990;31(suppl):221.

76 Jackson R, Morris DJ, Cooper RJ, et al. Multiplex polymerase chain reaction for adenovirus and herpes simplex virus in eye swabs. $\mathcal{F}$ Virol Methods 1996; 56:41-8.

77 Yamamoto S, Pavan-Longston D, Kinoshita S, et al. Detecting herpesvirus DNA in uveitis using the polymerase chain reaction. Brf Ophthalmol 1996; 80:465-8.

78 De Boer JH, Verhagen C, Bruinenberg M, et al. Serologic and polymerase chain reaction analysis of intraocular fluids in the diagnosis of infectious uveitis. Am f Ophthalmol 1996;121:650-8.

79 Uchio E, Yamazaki K, Aoki K, et al. Detection of enterovirus 70 by polymerase chain reaction in acute hemorrhagic conjunctivitis. $\mathrm{Am} \mathcal{F} \mathrm{Oph}$ thalmol 1996;122:273-5.

80 Zamora RL, Del Priore LV, Storch GA, et al. Multiple recurrent branch retinal artery occlusions associated with varicella zoster virus. Retina 1996;16: 399-404.

81 Fox GM, Crouse CA, Chuang EL, et al. Detection of herpesvirus DNA in vitreous and aqueous specimens by the polymerase chain reaction. Arch Ophthalmol 1991;109:266-71.

82 Bassili SS, Peyman GA, Gebhardt BM, et al. Detection of Epstein-Barr virus DNA by polymerase chain reaction in the vitreous from a patient with Vogt-Koyanagi-Harada syndrome. Retina 1996;16:160-1.

83 Abe T, Tsuchida, Tamai M. A comparative study of the polymerase chain reaction and local antibody production in acute retinal necrosis syndrome and cytomegalovirus retinitis. Graefes Arch Clin Exp Ophthalmol 1996;234: 419-24.

84 Nasir MA, Jaffe GJ. Cytomegalovirus retinitis associated with Hodgkin's disease. Retina 1996;16:324-7.

85 Waddell KM, Lewallen S, Lucas SB, et al. Carcinoma of the conjunctiva and HIV infection in Uganda and Malawi. Br f Ophthalmol 1996;80:503-8.

86 Holland SM, Hudson AP, Bobo L, et al. Demonstration of chlamydial RNA and DNA during a culture-negative state. Infect Immun 1992;60:2040-7.

87 Pecharatana S, Pickett MA, Watt PJ, et al. Genotyping ocular strains of Chlamydia trachomatis by single-tube nested PCR. PCR Methods Appl 1993;3:200-4

88 Elnifro EM, Storey CC, Morris DJ, et al. Polymerase chain reaction for detection of Chlamydia trachomatis in conjunctival swabs. BrF Ophthalmol 1997;81:497-500

89 Isobe K, Aoki K, Itoh N, et al. Serotyping of Chlamydia trachomatis from inclusion conjunctivitis by the polymerase chain reaction and restriction fragment length polymorphism analysis. Fpn f Ophthalmol 1996;40:279-85.

90 Talley AR, Garcia-Ferrer F, Laycock KA, et al. The use of polymerase chain reaction for the detection of chlamydial keratoconjunctivitis. $\mathrm{Am} \mathcal{F}$ Ophthalmol 1992;114:685-92.

91 Kessler HH, Pierer K, Stuenzner D, et al. Rapid detection of Chlamydia trachomatis in conjunctival, pharyngeal, and urethral specimens with a new polymerase chain reaction assay. Sex Transm Dis 1994;21:191-5.

92 Kowalski RP, Uhrin M, Karenchak LM, et al. Evaluation of the polymerase chain reaction test for detecting chlamydial DNA in adult chlamydial conjunctivitis. Ophthalmology 1995;102:1016-9.

93 Tabrizi SN, Lees MI, Garland SM. Comparison of polymerase chain reaction and culture techniques for detection of Chlamydia trachomatis. Mol Cell Probes 1993;7:357-60.

94 Bobo L, Munoz B, Viscidi R, et al. Diagnosis of Chlamydia trachomatis eye infection in Tanzania by polymerase chain reaction/enzyme immunoassay. Lancet 1991;338:847-50.

95 Hammerschlag MR, Robin PM, Gelling M, et al. Use of polymerase chain reaction for the detection of Chlamydia trachomatis in ocular and nasopharyngeal specimens from infants with conjunctivitis. Pediatr Infect Dis f 1997; 16:293-7.

96 Grenzebach UH, Busse H, Tötsch M, et al. Endophthalmitis induced by atypical mycobacterial infection. Ger f Ophthalmol 1996;5:202-6.

97 Brézin AP, Egwuagu CE, Burnier M, et al. Identification of Toxoplasma gondii in paraffin-embedded sections by the polymerase chain reaction. $\mathrm{Am}$ f Ophthalmol 1990;110:599-604.

98 Kwok S, Higuchi R. Avoiding false positives with PCR. Nature 1989;339:237

99 Wiedbrauk DL, Werner JC, Drevon AM. Inhibition of PCR by aqueous and vitreous fluids. F Clin Microbiol 1995;33:2643-6. 
100 Cone RW, Hobson AC, Huang ML. Coamplified positive control detects inhibition of polymerase chain reactions. F Clin Microbiol 1992;30:3185-9.

101 Klapper PE, Jungkind DL, Fenner T, et al. Multicenter international work flow study of an automated polymerase chain reaction instrument. Clin Chem 1998;44:1737-9.

102 Miyashita N, Matsumoto A, Niki Y, et al. Evaluation of the sensitivity and specificity of a ligase chain reaction test kit for the detection of Chlamydia trachomatis. F Clin Pathol 1996;49:515-7.

103 Gordon YJ. Rapid diagnosis tests for infectious ocular disease. Int Ophthalmol Clin 1993;33:153-61.
104 Mantell J, Goh BT, Woodland RM, et al. Dual infection of the conjunctiva with herpes simplex virus and Chlamydia trachomatis. Sex Transm Dis with herpes simpl

105 Deutsch FH. Concurrent adenoviral and herpetic ocular infections. Ann Ophthalmol 1989;21:432-8.

106 Mellman-Rubin TL, Kowalski RP, Uhrin M, et al. Incidence of adenoviral and chlamydial coinfection in adult follicular conjunctivitis. Am f Ophthalmol 1995;119:652-4.

107 Walpita P, Darougar S. Double-label immunofluorescence method for simultaneous detection of adenovirus and herpes simplex virus from the eye. F Clin Microbiol 1989;27:1623-5.

\section{British fournal of Ophthalmology - http://www.bjophthalmol.com}

Visitors to the world wide web can now access the British fournal of Ophthalmology either through the BMJ Publishing Group's home page (http://www.bmjpg.com) or directly by using its individual URL (http://www.bjophthalmol.com). There they will find the following:

- Current contents list for the journal

- Full text of the issue

- Contents lists of previous issues

- Members of the editorial board

- Information for subscribers

- Instructions for authors

- Details of reprint services.

A hotlink gives access to:

The web site is at a preliminary stage and there are plans to develop it into a more sophisticated site. Suggestions from visitors about features they would like to see are welcomed. They can be left via the opening page of the BMJ Publishing Group site or, alternatively, via the journal page, through "about this site".
- BMJ Publishing Group home page

- British Medical Association web site

- Online books catalogue

- BMJ Publishing Group books. 